\title{
The Need of a Systemic Approach in Climate Change Education: the Example of the EIT Climate-KIC Journey Summer School
}

\author{
Marinella Passarella \\ Resources Innovation Center Leoben, Montanuniversität Leoben, RIC Leoben, Leoben, Austria
}

Received July 31, 2021; accepted August 30, 2021; published online September 29, 2021

\begin{abstract}
Climate change is a "super wicked" problem. Policy regulation and research suggest that a systemic approach is needed and that education is a key element of the necessary multi-disciplinary, transformative, and holistic solutions. Higher education institutions can play a crucial role in facilitating mitigation and adaptation by enabling and empowering young generations to act. This article presents the work of Montanuniversität Leoben Resources Innovation Center (MUL RIC) in climate education actions, within the framework of EIT Climate-KIC. It gives insights from the largest summer school regarding climate system innovation in the EU - "The Journey", which has been coorganized by MUL RIC since 2018. In this contribution, The Journey is shown as an example of a systemic approach applied to higher education as a driver of climate solutions. It also discusses how it relates to EU policy and to recommendations of higher education for climate change.
\end{abstract}

Keywords: Climate change, Higher education, Systemic solutions, Systemic approach, Teaching, EIT, Innovation

Die Notwendigkeit eines systemischen Ansatzes in der Klimabildung: Das Beispiel der EIT Climate-KIC Summer School „The Journey“

Zusammenfassung: Der Klimawandel ist ein "super wicked“ Problem. Politik und Forschung legen nahe, dass ein systemischer Ansatz erforderlich ist und dass Bildung ein Schlüsselelement für die notwendigen multidisziplinären, transformativen und ganzheitlichen Lösungen ist. Hochschuleinrichtungen können eine entscheidende Rolle bei der Ermöglichung von Minderungs- und Anpassungsstrategien spielen, indem sie junge Generationen zum Handeln

$\overline{\text { M. Passarella, PhD }(\bowtie)}$

Resources Innovation Center Leoben,

Montanuniversität Leoben, RIC Leoben,

Franz-Josef-Straße 18,

8700 Leoben, Austria

marinella.passarella@unileoben.ac.at befähigen und ermächtigen. Dieser Artikel stellt die Arbeit des Resources Innovation Center der Montanuniversität Leoben (MUL RIC) im Rahmen des EIT Climate-KIC im Bereich Klimabildungsmaßnahmen vor. Er gibt Einblicke in die größte Summer School für Klimasysteminnovation der EU, "The Journey”, welche seit 2018 vom MUL RIC mitorganisiert wurde. In diesem Artikel wird The Journey als Beispiel für einen systemischen Ansatz vorgestellt, der bei der Hochschulbildung als Treiber für Klimalösungen angewendet wird. Es wird auch erörtert, wie es sich auf die EU-Politik und auf Empfehlungen in der Hochschulbildung zum Klimawandel bezieht.

Schlüsselwörter: Klimawandel, Hochschulbildung, Systemische Lösungen, Systemischer Ansatz, Lehre, EIT, Innovation

\section{Introduction}

In order to mitigate climate change and limiting global warming to $1.5^{\circ} \mathrm{C}$ compared to pre-industrial levels, the last Intergovernmental Panel on Climate Change (IPCC) report [1] calls for a rapid cut of Green House Gasses (GHGs) emissions in all sectors and urgent transitions at an unprecedented scale in the industrial, energy, land, urban, and infrastructure systems [1].

\subsection{Policy Context}

The European Commission (EC) responds to the IPCC call with recognising the climate emergency by putting in place legislations and investments to promote actions for $\mathrm{GHGs}$ reductions to achieve climate neutrality by 2050 and $55 \%$ GHGs reduction by 2030 [2]. The Green Deal confirms that the European Institute of Innovation and Technology (EIT) facilitates education activities in the field of climate change [3]. This is thanks to the EIT Knowledge and Inno- 
vation Community's (KIC) focus on the knowledge triangle, where education encounters research and innovation, with the aim of supporting EU member states in dealing with pressing societal challenges $[4,5]$. According to the regulation [4], the EIT, through the KICs, supports the EU climate ambition of net-zero GHGs emission by 2050, the EU Green Deal, the United Nations Sustainable Development Goals (SDGs) and follows the Paris agreement [6].

The need of a systemic transformation involving all aspects of our society, highlighted by the IPCC, is reflected also in the new EIT Strategic Innovation Agenda [5], which calls for a systemic approach in pursuing solutions to address EU policy in regard to climate change. The EIT Climate-KIC transformation in Time Strategy for the period 2019-2022 indicates the direction of the work for the EIT Climate-KIC community through system innovation. The document suggests the application of a holistic approach, involving society, technology, economics, and politics to foster the needed transformation to tackle climate change [7]. The EC in its communication [2] envisages the need of acting in all EU sectors to reach climate neutrality, confirming the systemic nature of the solutions which need to be put in place in the EU.

Looking at the interconnection between earth system processes and sustainability governance recommendations, a framework to guide humanity's development, without crossing the limits set by nature, was proposed in 2009 by Rockström and colleagues [8]. The framework of planetary boundaries gained large interest among the scientific community and policy makers. The planetary boundary framework highlights that the threshold of climate change has already been dangerously crossed by humans. Furthermore, it formalises the interconnection and systemic natures of processes as climate change within the earth system.

It seems therefore that humanity is facing a systemic emergency, which needs systemic solutions.

\subsection{Educational Context}

To increase climate literacy, it is essential to enable people to take responsible decisions affecting climate; higher education institutions, like the Montanuniversität Leoben, play a crucial role in delivering the key education activities needed for enabling the transformative, cross-disciplinary and systemic solutions to the climate crisis [9], at the EU, national and local levels. The existing literature on climate change education suggests adopting a systemic view and approach, while teaching this topic or facilitating the ideation of climate change solutions.

Leichenko and O'Brien (2020) [10] give a viewpoint on the topic. The authors suggest include higher education activities concerning climate change within the wider context of the Anthropocene. They criticise that climate change education is largely thought in a narrow perspective: courses emphasise the physical process as well as rising emission evidence; solutions explored are usually based on business-as-usual policies, emerging technologies and behavioural intervention [10]. The authors propose that, in climate change education, humans should been seen as playing an active role in forcing large-scale system change.

According to the review in [11], education on climate change should stimulate a comprehension of interconnectedness. Furthermore, the authors state that system thinking is useful in climate change education for facilitating the understanding of the functioning of the world.

In order to open the students' horizons on the variety of existing possible transformative solutions to climate change, the inclusion of a holistic systemic approach and teaching about transformations in climate education is recommended; for example by highlighting the link between personal and political or technical and behavioural transformations [10].

\section{The Journey Summer School}

Since 2010, the EIT Climate-KIC and local partners have been organising the largest climate innovation summer school in Europe that has trained over 2500 participants [12]. Montanuniversität Leoben Resources Innovation Center (MUL RIC) has been an active partner organising one part of the programme hosting 160 participants since 2018 .

The Journey lasts four weeks in which graduates and young professionals from all over the world travel among three locations in Europe. The education focusses on climate action and innovation aiming at systems transformation and community building [12]. An intercultural, genderbalanced, and multidisciplinary stimulating environment is created among attendees; in 2020 alone, over 60 nationalities were represented [12]. Participants have varied backgrounds ranging from technical to humanities sciences, including artists and activists.

The systems thinking approach lies at the core of the pedagogy of The Journey. The programme aims at empowering and enabling young people to climate leadership, equipping them with skills and capabilities to become change makers; contextualised and participant-focussed learning leads to a personal transformation and purpose orientation aiming at system transformation [12]. The individual transformation is strengthened through network and community building. The programme is designed to enable young people to take climate actions in the system to which they belong, and to be prepared to complexity and uncertainty encompassed by the climate change topic [12].

The programme applies the CCPOC pedagogy-Content, Context, Peer teaching, Ownership, Continuous dialoguedeveloped for The Journey starting from the reality pedagogy and the student-centred pedagogy [13]. These two are respectively based on: reality of the experience of participants and autonomy and independence of learners [13]. In this approach, the students and the teachers are considered as being on the same level: their knowledge and experience have the same importance. Students are also stimulated to own and develop their learning [13]. Seven learning outcomes are associated with the development of the following competencies among students: being creative, holistic systemic thinking, social capital, managing uncertainty, and communication [13]. During the four 


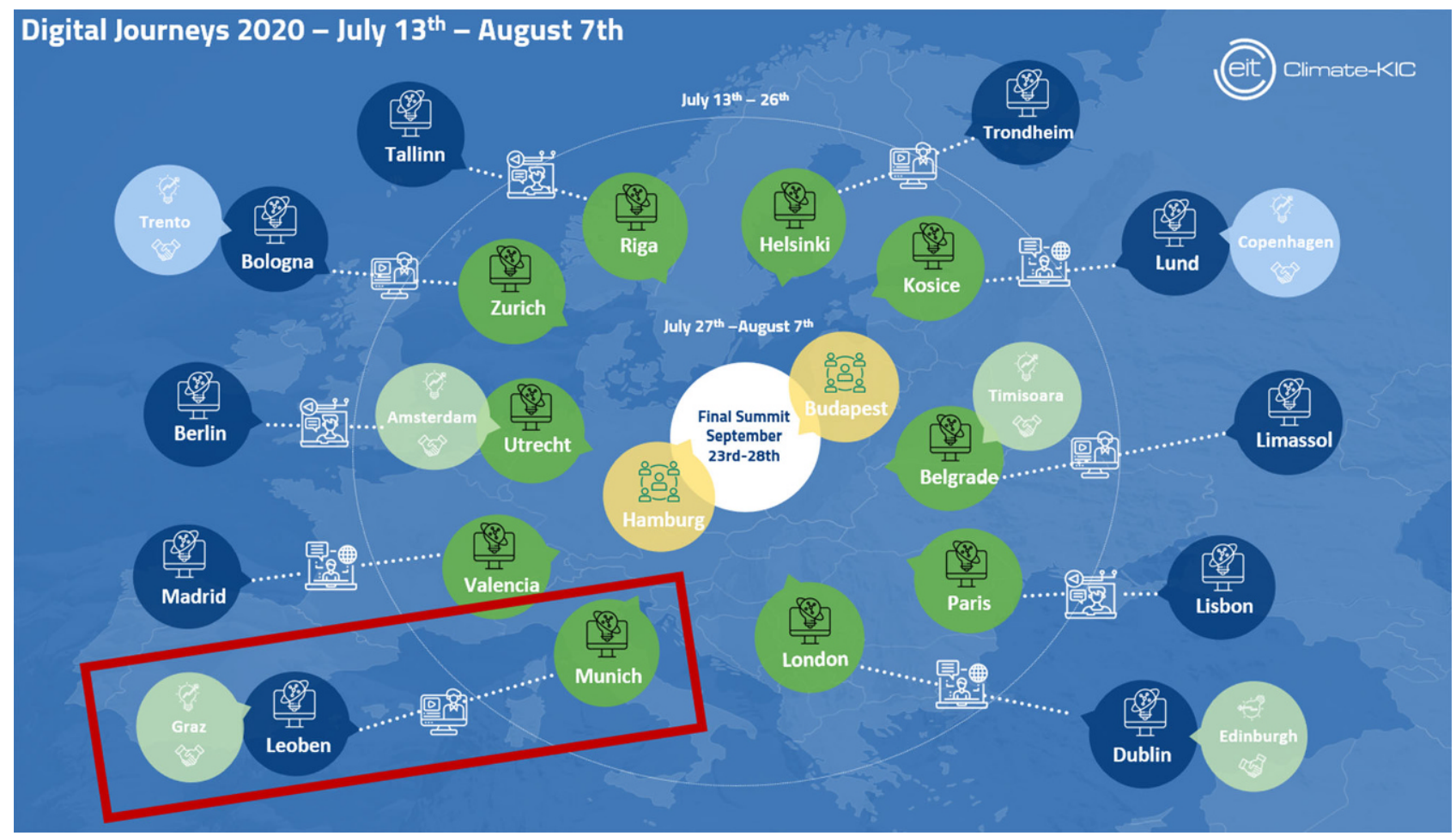

Fig. 1: The Journey summer school locations in 2020 (Courtesy of [12])

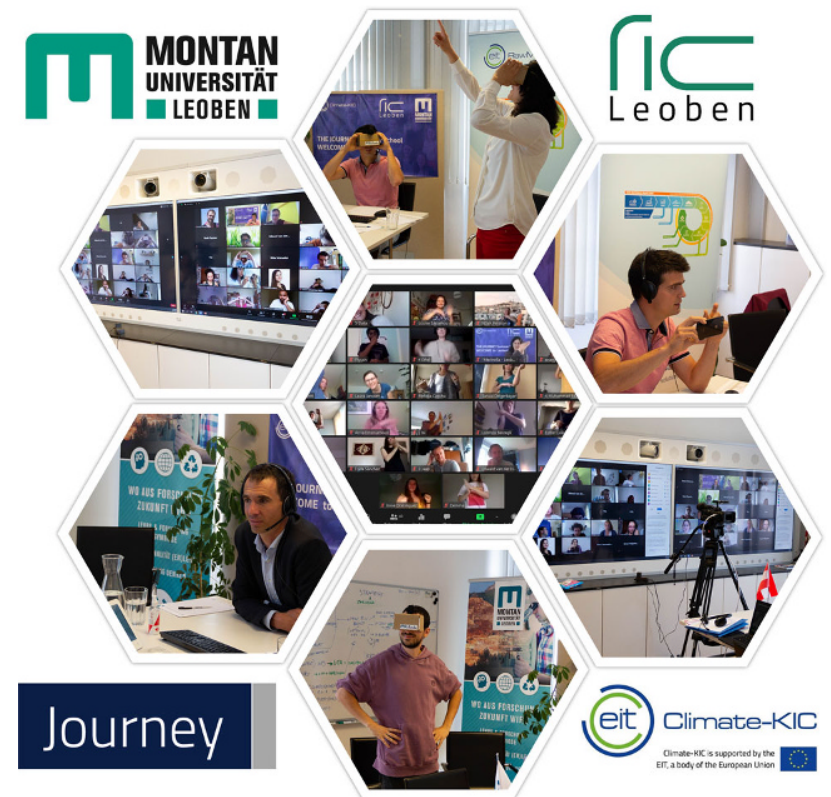

Fig. 2: The digital Journey at MUL RIC in 2020

weeks, the programme is organised around eight phases, which guide the participants towards the development of a group project to tackle climate change: sense making, framing, deciding, analysing, experimenting, planning, implementing, and consolidating [13].

MUL RIC has hosted part of the programme in the past three years. In 2018, it organised the last leg of The Journey including the showcase of the students' innovation and en- trepreneurial projects. In 2019 and 2020, RIC MUL hosted the first leg of the programme accompanying the participants at the beginning of their Journey adventure (Fig. 1).

In 2020 MUL RIC was a pioneer in delivering a digital education experience (Fig. 2) due to the pandemic.

Some highlights of the programme organised and offered by MUL RIC with European and local partners are:

- “Raw Material-Circularity and Sustainability \& Virtual Reality Site Visit". An interactive lecture was held by researchers of MUL. It showed how raw materials are used in every day-to-day material in different sectors, and the amounts consumed by the developed versus developing countries. This presentation showed the participants how raw materials are a necessity in today's society. It also encouraged participants to see how important it is to work towards a circular economy. Discussions highlighted that these aspects should be part of solutions for tackling climate change and for effectively implementing systemic change.

- An EIT Climate-KIC education expert led a comprehensive workshop on system thinking and mapping: "Shaping your mindset towards leadership for systems innovation". The participants were introduced to the basis of system thinking, system mapping, and leadership. This activity was applied in an offline outdoor exercise on system mapping.

- "Sustainability to enhance your value proposition: Convincing key drivers of change". A workshop provided by a researcher of VITO brought opportunities to analyse real complex projects from perspectives of various stakeholders and their interests. 
- "World Climate: Climate Change Negotiations Game" by [14]. This activity was organised and moderated by the University of Natural Resources and Life Sciences, Vienna (BOKU), Climate Change Centre Austria (CCCA), and RIC MUL. An interactive four-hour workshop simulated the United Nations climate change negotiations. During this role-playing exercise, the participants experienced how difficult it is to achieve an agreement between different countries with different interests and powers even for an urgent and pressing matter like the reduction in emission of GHGs.

- "Building a Sustainable Future." In this presentation and discussion by professors and researchers of TU Graz, the fields of sustainability in the building sector was explored. Participants dealt with: Development of building sustainability evaluation methods, Life cycle assessment (LCA) and evaluation of the environmental performance of products and buildings, Interdependencies of environmental and economic sustainability with functional and technical performance.

- "Plastic Waste Prevention". This workshop by WWF Austria and RIC MUL taught the participants about the recent rise of plastics and its environmental concerns. The focus was on plastic packaging. The participants learned how to distinguish "good" packaging from "bad" and discussed solutions for our plastic crisis as well as possible steps that can be taken into their daily lives to live more sustainably.

\section{Discussion and Conclusions}

The Journey has shown the alignment with EU policies and strategies and with the EIT agenda, by applying a systemic approach and allowing students to map different sector systems highlighting their interconnections. Furthermore, an international, diversified, multidisciplinary, and genderbalanced environment among the participant groups and peers has embraced European values, responding also to recommendations of [11] by learning from each other's different cultures and backgrounds.

Some activities and characteristics of The Journey mirror suggestions of the literature [10]:

1. The application of the "Climate Change Negotiations Game" critically showed the social and political aspects as well as balances of power and interests connected to GHGs emissions.

2. A strong sense of community along with individual agency (as suggested by [15]) is created within The Journey participants, alumni, and peers. This is directly pursued through participants' experience, which highlight their personal and collective potential for systemic cultural and personal transformation.

Looking at the RIC experience during The Journey, it appears that technical universities like MUL, which are included in multi-disciplinary climate change education programmes and curricula, represent an added value for students. In this way, it is possible to show topics and systems, which would be traditionally not be included in higher education classes on climate change. For example, participants at MUL have learnt to observe the need of raw materials in their every-day life activities and local contexts, thanks to lectures showing the essential role of raw materials in our society in sectors, such as building, infrastructure, mobility, energy, and production. The participants have reflected on the interconnections among these sectors and on the complexity of linkages of these aspects with societal ones. In this way, they could work on ideating systemic solutions contributing to tackle climate change, avoiding at the same time simplistic interpretation of the climate change emergency.

The climate change defined as a "super wicked" problem $[16,17]$ needs a systemic approach in the education. Examples, which can provide good practices, already exist: the system innovation provided by the interdisciplinary and transformative EIT Climate KIC summer school: The Journey.

Funding. Open access funding provided by Montanuniversität Leoben.

Open Access This article is licensed under a Creative Commons Attribu tion 4.0 International License, which permits use, sharing, adaptation, distribution and reproduction in any medium or format, as long as you give appropriate credit to the original author(s) and the source, provide a link to the Creative Commons licence, and indicate if changes were made. The images or other third party material in this article are included in the article's Creative Commons licence, unless indicated otherwise in a credit line to the material. If material is not included in the article's Creative Commons licence and your intended use is not permitted by statutory regulation or exceeds the permitted use, you will need to obtain permission directly from the copyright holder. To view a copy of this licence, visit http://creativecommons.org/licenses/by/4.0/.

\section{References}

1. Masson-Delmotte, V.; Zhai, P.; Pörtner, H.O.; Roberts, D.; Skea, J.; Shukla, P.R.; Pirani, A.; Moufouma-Okia, W.; Péan, C.; Pidcock, R.; Connors, S.; Matthews J.B.R.; Chen, Y.; Zhou, X..; Gomis, M.I.; Lonnoy, E.; Maycock, T.; Tignor, M.; Waterfield, T. (eds.): Summary for Policymakers. In: Global Warming of $1.5^{\circ} \mathrm{C}$. An IPCC Special Report on the impacts of global warming of $1.5^{\circ} \mathrm{C}$ above pre-industrial levels and related global greenhouse gas emission pathways, in the context of strengthening the global response to the threat of climate change, sustainable development, and efforts to eradicate poverty: IPCC, 2018

2. Stepping up Europe's 2030 climate ambition, European Commission, 17.09.2020, document COM (2020) 562 final

3. The European Green Deal, European Commission, 11.12.2019, document COM (2019) 640 final

4. Proposal for a regulation of the European Parliament and of the Council on the European Institute of Innovation and Technology (recast), 6259/21, RECH 66, COMPET 109, EDUC 54, CODEC 224

5. Proposal for a Decision of the European Parliament and of the Council on the Strategic Innovation Agenda of the European Institute of Innovation and Technology (EIT) 2021-2027: Boosting the Innovation Talent and Capacity of Europe, 17.02.2021, document 6258/21, RECH 65, COMPET 108, EDUC 53, CODEC 223

6. Paris Agreement of the parties to the United Nations Framework Convention on Climate Change, 04.11.2016, document C.N.92.2016

7. Transformation, in time EIT Climate-KIC Strategy 2019-2022: EIT Climate KIC, 2019

8. Rockström, J.; Steffen, W.; Noone, K.; Persson, Å.; Chapin, F.S.; Lambin, E.F.; Lenton, T.M.; Scheffer, M.; Folke, C.; Schellnhuber, H.J.; Nykvist, B.: A safe operating space for humanity, Nature, 461 (2009), no. 7263, pp 472-475 
9. Moosmayer, D. C.; Laasch, O.; Parkes, C.; Brown, K. G (eds.): The SAGE Handbook of Responsible Management Learning and Education, London: Sage, 2020

10. Leichenko, R.; O'Brien, K.: Teaching climate change in the Anthropocene: An integrative approach, Anthropocene, 30 (2020), no. 100241, pp 1-4

11. Cook, J. W. (ed): Sustainability, Human Well-Being, and the Future of Education, Helsinki: Palgrave Macmillan, 2019

12. Climate-KIC: The Journey, https://journey.climate-kic.org/ (15.07.2021)

13. Saunders, E. (ed.): EIT Climate-KIC The Journey Manual, 2020

14. Climate Interactives: Tools for a thriving future, https://www. climateinteractive.org/tools/world-climate-simulation/ (15.07.2021)

15. Petersen, B.; Barnes, J.R.: From hopelessness to transformation in geography classrooms. Journal of Geography, 119 (2020), pp 3-11
16. Levin, K.; Cashore, B.; Bernstein, S. and Auld, G.: Playing it forward: path dependency, progressive incrementalism, and the "Super Wicked" problem of global climate change, in: IOP Conference Series, Earth and Environmental Science: IOP Publishing, 6 (2009), no. 50 , pp 1-2

17. Levin, K.; Cashore, B.; Bernstein, S.; Auld, G.: Overcoming the tragedy of super wicked problems: constraining our future selves to ameliorate global climate change. Policy sciences, 45 (2012), no 2, pp 123-152

Publisher's Note. Springer Nature remains neutral with regard to jurisdictional claims in published maps and institutional affiliations. 